\title{
A revision of the genus Aciculopsora (Ramalinaceae), with the description of one new species and one new combination
}

\author{
Sonja Kistenich ${ }^{1 *}$, Mika Bendiksby ${ }^{1,2}$, Gothamie Weerakoon ${ }^{3}$ \& Einar Timdal ${ }^{1}$
}

\author{
Article info \\ Received: 1 Sept. 2019 \\ Revision received: 9 Nov. 2019 \\ Accepted: 10 Nov. 2019 \\ Published: 2 Jun. 2020 \\ Associate Editor \\ Damien Ertz
}

\begin{abstract}
The tropical lichen genus Aciculopsora is still very poorly collected. Only eleven collections are known worldwide. We present a molecular phylogenetic tree based on mtSSU and nrITS sequence data from six Aciculopsora specimens. Our results corroborate the monophyly of the genus. We conclude that Aciculopsora consists of three species: A. cinerea, A. longispora comb. nov. (三 Phyllopsora longispora, $=$ A. salmonea syn. nov.) and $A$. srilankensis sp. nov. Aciculopsora cinerea occurs in Brazil, A. longispora in Argentina, Costa Rica, Ecuador, and Kenya, and A. srilankensis in Sri Lanka. As such, the genus is new for the Paleotropics, Argentina and Ecuador.
\end{abstract}

Key words: Argentina, Ecuador, Galapagos, Phyllopsora, rainforest, Sri Lanka, taxonomy, tropics

\section{Introduction}

Aptroot et al. (2006) described the lichen genus Aciculopsora for the single species A. salmonea from two localities in dry semi-deciduous forests in Costa Rica. Based on morphological characters, the genus was placed in the Ramalinaceae (Lecanorales, Lecanoromycetes) and discussed against Bacidiopsora, Phyllopsora and Squamacidia. The main diagnostic characters for the new genus were ascospore shape, apothecium pigmentation, squamule and prothallus morphology, and the lack of secondary substances. A second species of Aciculopsora, A. cinerea, was described in Cáceres (2007) from a single collection made in the Atlantic Forest in Brazil.

In a 5-locus phylogenetic study of the Ramalinaceae, Kistenich et al. (2018a) recovered A. salmonea in a strongly supported clade sister to a clade consisting of Scutula and Parallopsora labriformis. In Kistenich et al. (2019a) a close phylogenetic relationship was indicated between 'Phyllopsora' longispora and A. salmonea based on unpublished sequences, and the former was hence excluded from Phyllopsora although without a new generic placement.

Revision of herbarium material for our studies on Phyllopsora (Kistenich et al. 2019a, b) and recent

\footnotetext{
${ }^{1}$ Natural History Museum, University of Oslo, P.O. Box 1172 Blindern, 0318 Oslo, Norway

${ }^{2}$ NTNU University Museum, Norwegian University of Science and Technology, Erling Skakkes Gate 47A, 7012 Trondheim, Norway

${ }^{3}$ Algae, Fungi and Plants Division, Department of Life Sciences, The Natural History Museum, Cromwell Road, London SW75BD, UK

* Corresponding author e-mail: sonja.kistenich@gmail.com
}

fieldwork in Sri Lanka (2017) have yielded additional material relevant to the circumscription of Aciculopsora. This paper presents the first molecular phylogeny and an updated taxonomy of the genus.

\section{Materials and methods}

\section{Taxon sampling}

For this study we investigated the isotype of $A$. salmonea and the holotype of $A$. cinerea, borrowed from BR and B, respectively. Previously we published DNA sequences of A. salmonea in our study of the family Ramalinaceae (Kistenich et al. 2018a). During the revision of the tropical genus Phyllopsora, we discovered further specimens belonging in Aciculopsora. Hence, we also investigated by morphology the holotype of Phyllopsora longispora (UPS) and three additional specimens, also originally identified by us as $P$. longispora, collected in Ecuador (herb. Z. Palice), Galapagos (CDS) and Kenya (herb. S. Pérez-Ortega). After initial submission of the manuscript, unpublished ITS sequences from two collections (TU) of an Aciculopsora sp. recently collected in Argentina were made available to us by A. Suija. In addition, we include two tentatively named 'Phyllopsora' specimens from Sri Lanka (PDA), previously found to fall outside the genus Phyllopsora in our recent molecular study on the genus in Asia (Kistenich et al. 2019b). In total, eight specimens were investigated for this study (Table 1). Author names for the studied species are given in Table 1. 


\section{Morphology and secondary chemistry}

Regarding the procedures employed for morphological and chemical analyses, see the Methods section in Kistenich et al. (2018b).

\section{Molecular methods}

The molecular methods for DNA extraction, PCR amplification and Sanger sequencing of the mitochondrial ribosomal small subunit (mtSSU) and of the nuclear ribosomal internal transcribed spacer region (ITS: ITS1, 5.8S, ITS2) followed those described by Kistenich et al. (2018b).

\section{Phylogenetic analyses}

We assembled the raw sequence reads with Geneious R9 (Kearse et al. 2012). The mtSSU and ITS sequences were aligned separately using the MAFFT plugin (Katoh \& Standley 2013) in Geneious with the E-INS-i algorithm and the nucleotide scoring matrix set to 10PAM $/ \kappa=2$. We trimmed the 5 '-end of the mtSSU alignment slightly to reduce the amount of missing data and for the ITS alignment to comprise only the ITS region, i.e. deleting the residual $18 \mathrm{~S}$ and $28 \mathrm{~S}$ sequence information. Each alignment was initially analysed by IQ-TREE v.1.6.7 (Nguyen et al. 2015) to infer a maximum likelihood tree using 1000 standard non-parametric bootstrap repetitions. We checked for gene tree incongruence using compat.py (Kauff \& Lutzoni 2002) with a cut-off of 60 . For the final phylogenetic analyses we concatenated the two markers and subjected the dataset to a detailed IQ-TREE analysis to find the best-fitting nucleotide substitution models and partitioning schemes (Chernomor et al. 2016; Kalyaanamoorthy et al. 2017) among the models implemented in MrBayes (i.e. 1-, 2- and 6-rate models) and to infer a maximum likelihood tree with 1000 standard non-parametric bootstrap repetitions. We defined four subsets, one for $\mathrm{mtSSU}$ and three for ITS corresponding to the ITS1, 5.8S and ITS2 regions, and analysed those with the TESTMERGE function resembling PartitionFinder2. In addition, we analysed the dataset with MrBayes v.3.2.6 (Altekar et al. 2004; Ronquist \& Huelsenbeck 2003) as described in Kistenich et al. (2018b). Three length parameter $\alpha / \beta$ was set to 3.4 and the temperature increment parameter to 0.15 . We projected the bootstrap support (BS) values from the IQ-TREE analysis onto the MrBayes consensus tree with posterior probabilities (PP) and collapsed branches with $\mathrm{BS}<50$ and $\mathrm{PP}<0.7$. The resulting trees were edited in TreeGraph2 (Stöver \& Müller 2010).

\section{Results}

\section{Morphology and secondary chemistry}

In total, we subjected eight specimens to morphological and chemical analyses. Specimen \#1042 is morphologically nearly identical with the holotype of $P$. longispora. As this specimen was collected close to the type locality of that species (Kakamega National Park, Kenya), we regard it as representative of $P$. longispora. Specimens \#1544 and \#7377 were collected from the Ecuador mainland and the
Galapagos Islands, respectively. Morphologically they are very similar to the specimens from Kenya (e.g., isidiate) and are tentatively named $P$. longispora. No vegetative dispersal propagules were observed in the fertile specimens of $A$. salmonea and $A$. cinerea. In contrast, the two specimens from Sri Lanka are sorediate. All specimens lack secondary metabolites as determined by thin-layer chromatography (TLC).

\section{Molecular data and phylogenetic analyses}

We generated three new mtSSU and three new ITS sequences (Table 1) for this study, in addition to the previously published sequences of $A$. salmonea and the Sri Lankan specimens. The holotype of $A$. cinerea did not yield sequences. To place the newly generated sequences in a comprehensive molecular phylogeny, we included mtSSU and ITS sequences of 28 additional specimens (Table 1) representing all genera that constitute clade ' $D$ ' in Kistenich et al. (2018a: Fig. 2). Further new sequences were generated for Physcidia wrightii and 'Phyllopsora' soralifera. The final mtSSU alignment consisted of 34 accessions with a length of $835 \mathrm{bp}$ and contained $6 \%$ missing data. The final ITS alignment consisted of 26 accessions with a length of 628 bp and contained $9.7 \%$ missing data. The compat.py software did not report any incongruence between the gene trees, so we concatenated the alignments for the final phylogenetic analyses. The final alignment is available from TreeBase (study no. 25026). Bellicidia incompta was used for rooting of all generated trees. IQ-TREE suggested the following nucleotide substitution models for the four predefined subsets: GTR $+\mathrm{I}+\Gamma$ for $\mathrm{mtSSU}, \mathrm{K} 2 \mathrm{P}+\Gamma$ for ITS1, $\mathrm{K} 2 \mathrm{P}+\mathrm{I}$ for $5.8 \mathrm{~S}$, and GTR $+\mathrm{G}$ for ITS2. The Bayesian phylogenetic analysis halted automatically after 3 million generations, when the ASDSF in the last $50 \%$ of each run had fallen below 0.01 . Following a burn-in of $50 \%$, we used 6,004 trees for the final Bayesian majority-rule consensus tree. The phylogenetic topologies generated by IQ-TREE vs. MrBayes showed no incongruence except for one conflict involving weakly supported terminal branches within the genus Krogia. This incongruence did not affect the phylogenetic relationships of the genus Aciculopsora, and the respective clade was collapsed to a polytomy. The extended majority-rule consensus tree, based on the Bayesian topology with all compatible groups (Fig. 1, $\mathrm{BS} \geq 50$ and/or $\mathrm{PP} \geq 0.7$ ), shows a well-resolved topology which is congruent with that of clade ' $D$ ' in Kistenich et al. (2018a). The six accessions of Aciculopsora comprise a strongly supported clade, forming a larger, well-supported clade with the genera Scutula and Parallopsora. The specimens originally identified as Phyllopsora longispora group together with the isotype of A. salmonea in a strongly supported clade. The Sri Lankan accessions (\#6768, \#6769) are separated, with strong support from the remaining four Aciculopsora specimens. The two specimens from Argentina were identified as A. longispora by a local BLASTn search of their unpublished ITS sequences and by incorporation into the ITS tree (not shown). 


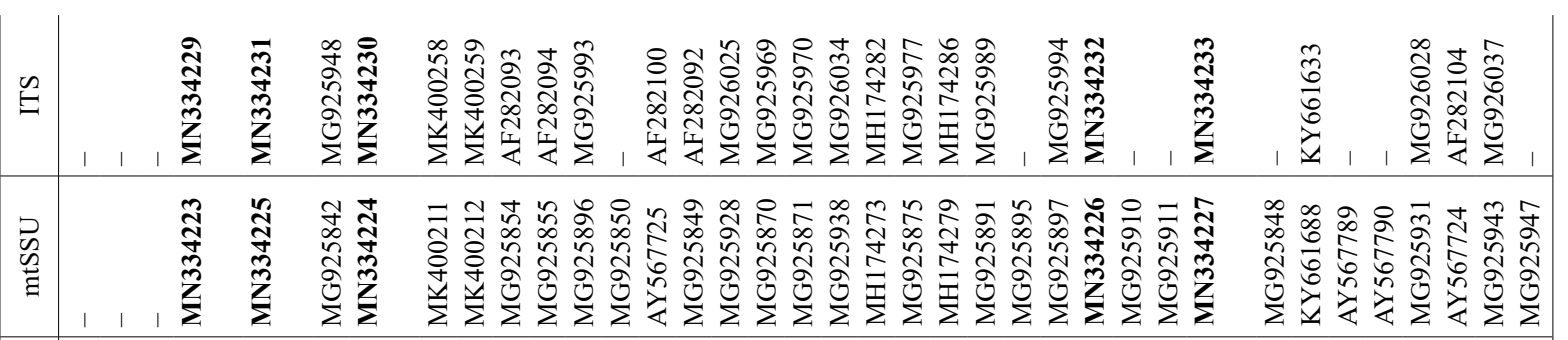

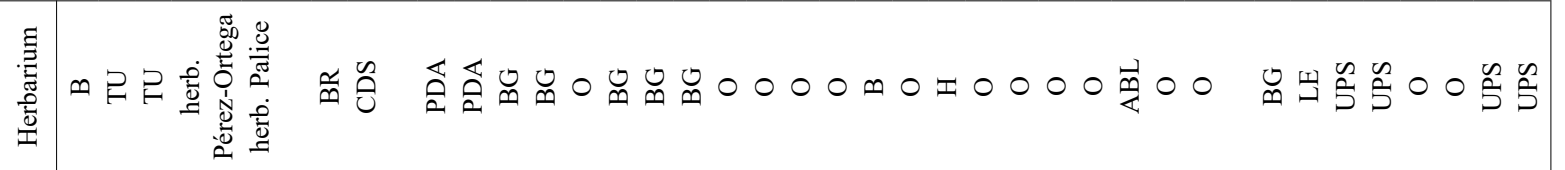

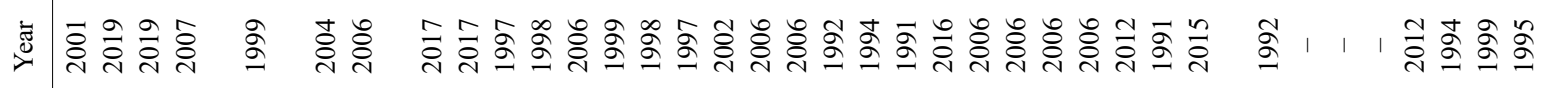
(n)

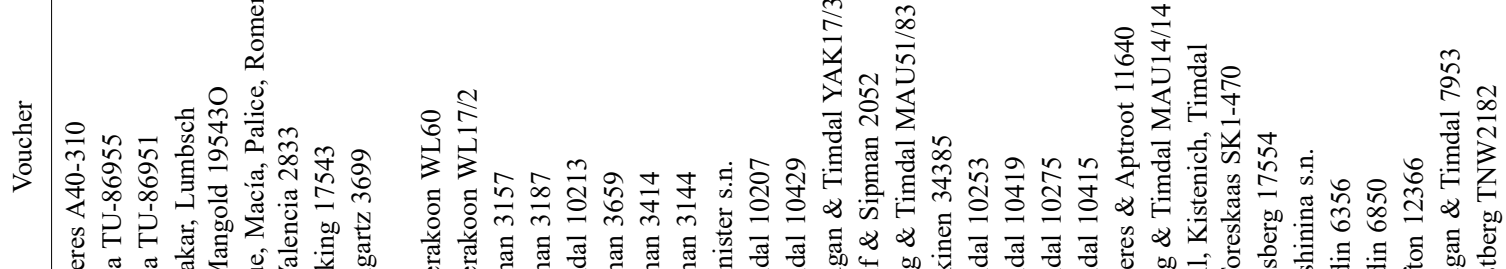

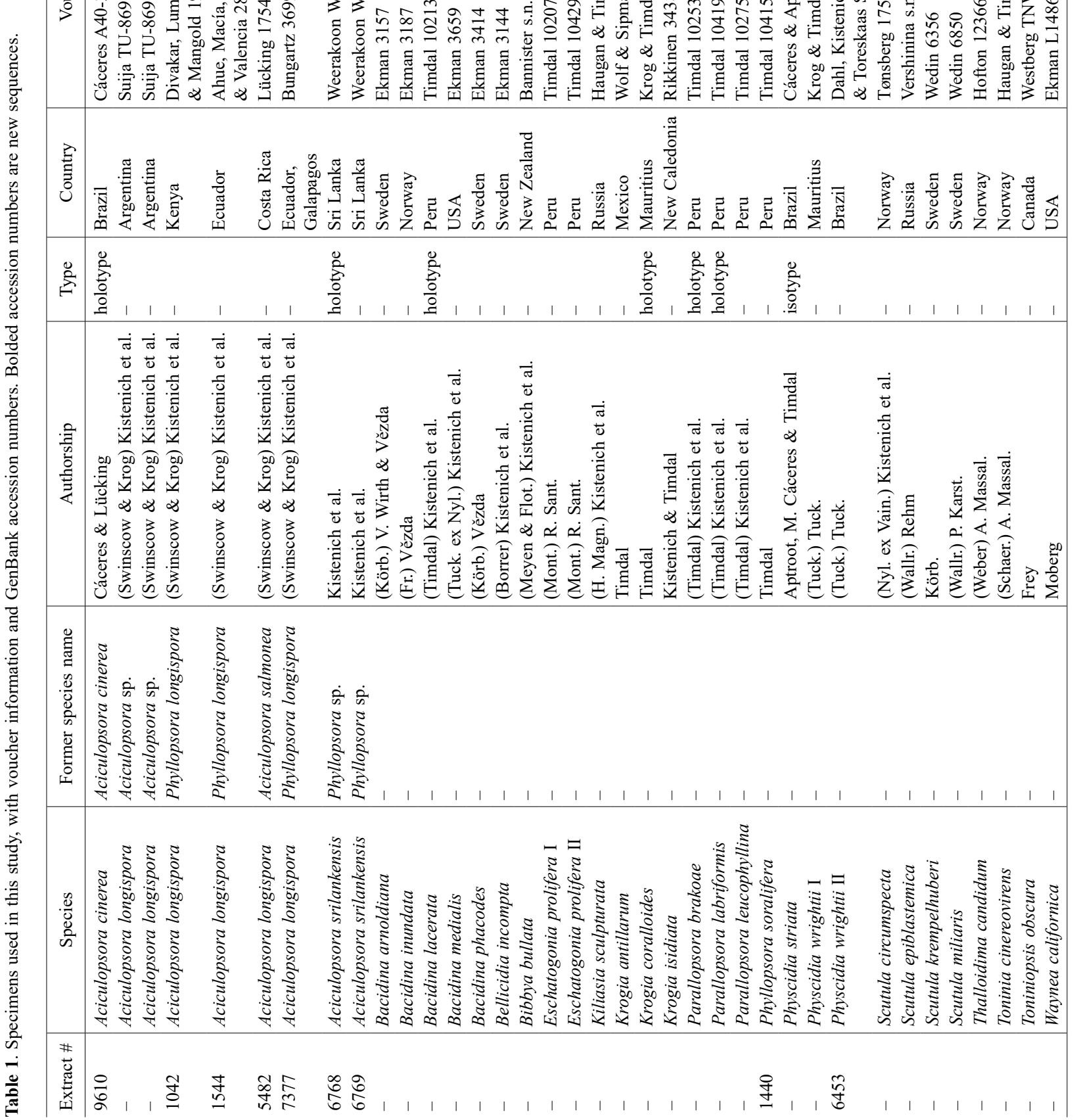




\section{Discussion}

The genus Aciculopsora was first described in 2006 by Aptroot and Trest (Aptroot et al. 2006) with the single species $A$. salmonea known from two collections. One year later, Cáceres and Lücking (Cáceres 2007) described the species $A$. cinerea based on a single collection of less than $4 \mathrm{~cm}^{2}$ (Fig. 2). Until now, these three collections comprised the complete knowledge of the genus; little was known about its distribution range in the Neotropics or its potential occurrence in the Paleotropics. In this study we revised the taxonomy of the genus, using molecular phylogenetic results in combination with morphological and chemical data.

All accessions of Aciculopsora form a well-supported monophyletic group in a clade with the genus Scutula and members of Parallopsora (Fig. 1). This topology is similar to the relationships resolved in Kistenich et al. (2018a). In contrast to the tropical genus Parallopsora, members of the temperate genus Scutula comprise both lichenized and lichenicolous fungi. Their close relation to Aciculopsora seems therefore rather surprising, but Kistenich et al. (2018a) showed repeated transitions from temperate habitats to the tropics in all major clades of the family Ramalinaceae.

In our multi-locus phylogeny (Fig. 1), two strongly supported clades can be distinguished. The first clade comprises the three specimens originally identified as Phyllopsora longispora and the isotype of $A$. salmonea, their accessions additionally split into Neotropical and Paleotropical specimens. The second clade comprises the sorediate specimens from Sri Lanka. Phyllopsora longispora was previously known from only a single collection from Kenya (Fig. 3A), taken in 1970 and thus unsuitable for standard Sanger sequencing. Its occurrence in other tropical parts of the world was unexplored. Specimen \#1042 (Fig. 3B) was collected in the same area, Kakamega National Park, as the holotype of P. longispora, and is morphologically very similar to the type specimen. The two Ecuadorian specimens (Fig. 3C-D) are also morphologically very similar despite the huge geographic distance. As the isotype of $A$. salmonea (Fig. 3E) is nested among those specimens in the phylogenetic tree (Fig. 1) and in both gene trees (not shown), we re-examined all specimens morphologically. Unlike the characteristic salmon colour in the apothecia of the A. salmonea type, the corresponding pigment in the fertile $P$. longispora specimens (\#1042 and \#7377) was observed to be rather brownish. In addition, $A$. salmonea has not been reported to form isidia, unlike all of our P. longispora specimens. However, the two Argentinean specimens also lack isidia and they group into the same phylogenetic clade (not shown). The presence or absence of vegetative propagules, in particular isidia, has been reported to be an unreliable diagnostic character in species of, for instance, the morphologically and ecologically similar genus Phyllopsora, also of the Ramalinaceae (Brako 1991; Kistenich et al. 2019a, b). With only two collections of $A$. salmonea known, the extent of morphological variation within this species probably is insufficiently documented. Nor did we observe the
P. longispora specimens to form a monophyletic group in any of the two gene trees (not shown). We therefore conclude that $P$. longispora and $A$. salmonea are conspecific and reduce the latter to synonymy by making the new combination A. longispora. It may be discussed whether $A$. longispora in its new circumscription comprises one or two species based on the strongly supported split into Neotropical and Paleotropical specimens (Fig. 1). Their terminal branches are rather short but are as long as those found in the neighbouring genus Scutula. However, the lack of morphologically diagnostic characters makes us refrain from splitting the species. Similar phylogenetic patterns correlating with geographical distance could also be observed within Phyllopsora (Kistenich et al. 2019a, b).

The new species $A$. srilankensis (Fig. 4) is clearly distinct from $A$. longispora based on its mode of vegetative dispersal and the rather long branch in the phylogenetic tree (Fig. 1). Aciculopsora srilankensis forms soredia (Fig. 4B) and may thus be readily distinguished from $A$. longispora and A. cinerea. Young or poorly developed specimens lacking apothecia and soredia may be challenging to assign to the correct species, though, as the general thallus morphology overlaps with the other two Aciculopsora species. Hence, DNA sequences seem to be the best means of reliably identifying young specimens so far. Further collections need to be made to explore their morphological variability and possibly find additional differences between the species. Soredia may also be found in other closely related genera, such as in Parallopsora and in the orphaned species 'Phyllopsora' sorediata, but are otherwise rare in clade ' $D$ ' (sensu Kistenich et al. 2018a: Fig. 2), indicating the taxonomic importance of this type of vegetative dispersal.

Unfortunately we were not able to generate sequences of $A$. cinerea (Fig. 2). We still consider it a well-distinguished species based on its small apothecia with a grey disc, shorter ascospores and lack of vegetative dispersal propagules, in contrast to the two other species. However, we cannot exclude the possibility that the holotype of $A$. cinerea merely represents a young and/or poorly developed specimen that was not able to grow to its full size or form soredia/isidia. Fresh material from the Mata Atlântica will be needed for generation of DNA sequences to help elucidate its relationship to A. longispora and A. srilankensis.

When examining asci of $A$. longispora (Fig. 5A-C) and A. srilankensis (Fig. 5D-G), we found them to resemble the almost non-amyloid asci characteristic for the tropical genus Krogia. However, in addition to macro-morphological characters (e.g., the presence of patchy red pigment in the thallus and apothecia in all species of Krogia), species of Aciculopsora are easily distinguished by the linear arrangement of ascospores in the ascus, in contrast to the spiral arrangement in species of Krogia. In only a single ascus of $A$. srilankensis (Fig. 5G) we found a partly spiral arrangement of ascospores, but never as strong as we observed in asci of Krogia. Furthermore, the molecular phylogeny shows that these two genera belong to two different larger groups (Fig. 1) and are not sister genera, indicating that the presence of a non-amyloid ascus might 


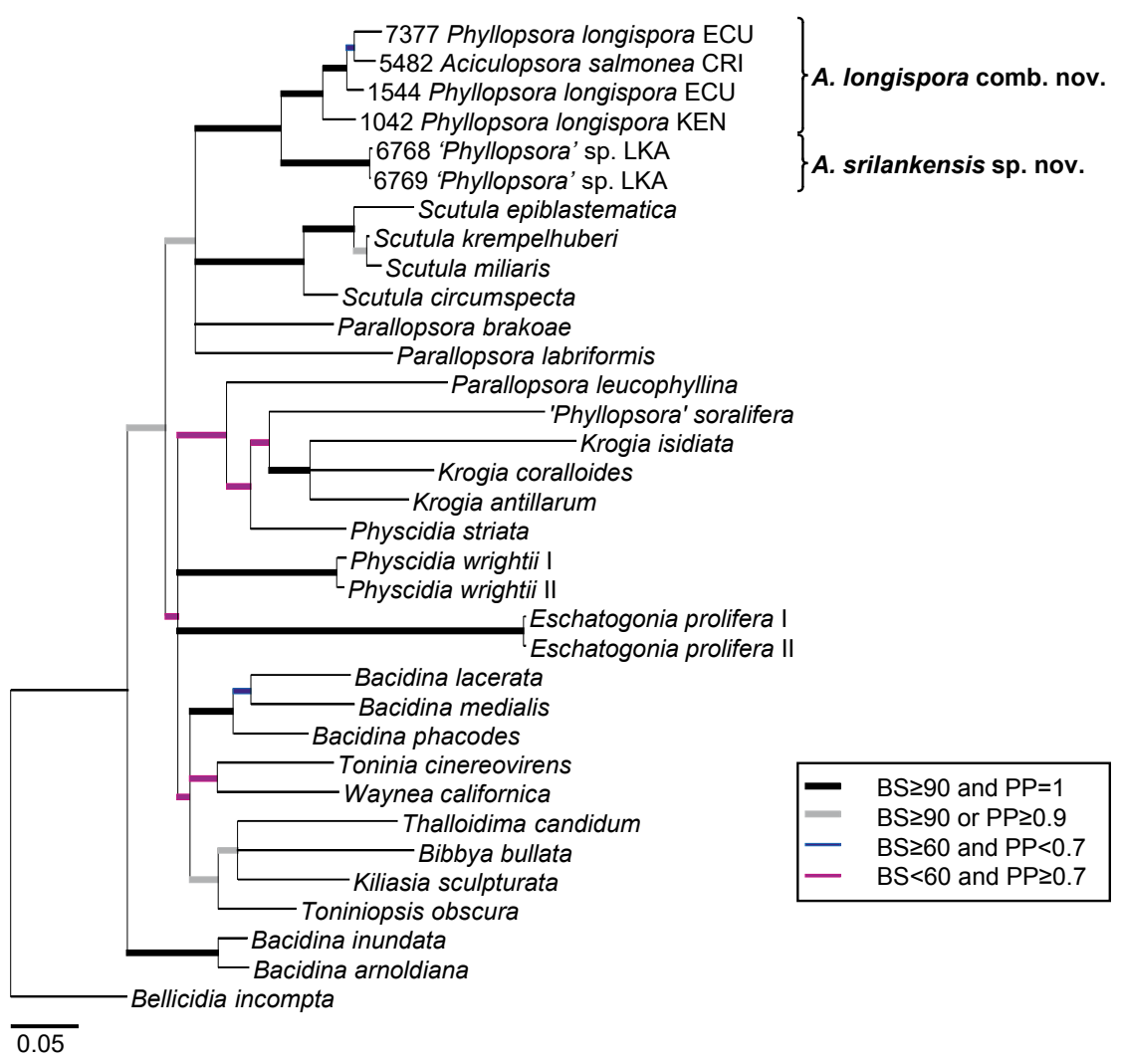

Figure 1. Extended majority-rule consensus tree resulting from MrBayes analysis of the mtSSU and ITS alignment with IQ-TREE maximum likelihood $\mathrm{BS} \geq 50$ and/or Bayesian $\mathrm{PP} \geq 0.7$ and branch lengths. Strongly supported branches (BS $\geq 90$ and $\mathrm{PP}=1$ ) are bolded; branches supported with $\mathrm{BS} \geq 90$ or $\mathrm{PP} \geq 0.9$ are bolded grey; branches supported with $\mathrm{BS} \geq 60$ and $\mathrm{PP}<0.7$ are bolded blue; branches supported with $\mathrm{BS}<60$ and $\mathrm{PP} \geq 0.7$ are bolded magenta. Bellicidia incompta was used for rooting. Aciculopsora accession names include the official three-letter country codes according to ISO 3166-1 alpha-3.

have evolved independently. Unfortunately, there was too little material for us to investigate ascus structure in A. cinerea, but we assume that there would be a similar staining reaction. We do not know any other species or genus with the same type of ascus in the Ramalinaceae.

With this study we have raised the known number of Aciculopsora specimens from three to eleven collections, and have extended the geographic occurrence of the genus from Costa Rica and Brazil to comprise further parts of the Neotropics, East Africa and Sri Lanka. As such, this is the first report of the genus from the Paleotropics. However, additional collections are essential to map the species distribution ranges and to investigate their morphological and genetic variability. The genus likely exists in other tropical countries as well, but collections are so far extremely rare. That might indicate that Aciculopsora species occur less frequently than species of other tropical genera such as Phyllopsora (including the former genus Crocynia) or Eschatogonia, with which it shares the same habitats and the 'phyllopsoroid' thallus growth form (i.e. squamules overgrowing a prothallus). As shown in the molecular phylogeny of the Ramalinaceae (Kistenich et al. 2018a), this growth form has evolved several times and may be found in all major clades comprising tropical species. Alternatively, the rarity of Aciculopsora specimens may result from insufficient identification due to the often poor development of specimens, and thus may merely represent an artefact. Either way, we encourage lichenologists to search for this poorly known genus in areas ranging from tropical wet rainforests to dry semi-deciduous forests. In particular, tropical islands frequently seem to harbour undescribed lichen species, as found, for instance, in the genus Krogia from Borneo, Malaysia and La Grande Terre, New Caledonia (Kistenich et al. 2018b). The islands of Galapagos and Sri Lanka are also generally known as biodiversity hotspots (e.g., Marchese 2015). Hence, we expect further occurrences of Aciculopsora to be reported from tropical islands in the future.

\section{Taxonomy}

Aciculopsora Aptroot \& Trest in Aptroot et al., J. Hattori Bot. Lab. 100: 618. 2006.

\section{MycoBank MB 29066}

Generic type: Aciculopsora salmonea Aptroot \& Trest [syn. A. longispora (Swinscow \& Krog) Kistenich, Bendiksby \& Timdal]

Description. Thallus corticolous, squamiform, composed of appressed, originally dispersed, later contiguous or overlapping squamules resting on a black prothallus; upper cortex paraplectenchymateous, 2-5 cells thick; photobiont unicellular green algae; medulla not amyloid; lower cortex absent. Apothecia lecideine, medium brown to dark brown, plane to somewhat convex, with \pm persistent, sharply raised, often darker margin, or sometimes immarginate even when young; excipulum pale to medium brown, composed of radiating, conglutinated, rather thick-walled hyphae with broadly ellipsoid to 
shortly cylindrical lumina; hypothecium colourless or pale brown; epithecium colourless; no crystals in apothecia; hymenium amyloid; paraphyses straight, unbranched, weakly conglutinated, with cylindrical lumina, with an apical cell not swollen and without pigment cap; ascus narrowly clavate, with a well-developed, faintly amyloid tholus often containing a lateral, conical, slightly deeper amyloid structure; ascospores acicular, straight or slightly curved, rarely spirally arranged in ascus, simple or with a few scattered septa. Pycnidia unknown. Chemistry: No lichen substances detected by TLC.

Notes. The genus Aciculopsora is here shown to consist of three species based on eleven collections. It was resolved in a clade with the genus Scutula and members of the genus Parallopsora by both Kistenich et al. (2018a: Fig. 2) and the present study (Fig. 1). In morphology it most closely resembles the genus Phyllopsora by forming small squamules on a well-developed prothallus. It may, however, be distinguished from the latter by forming long, often septate ascospores and by having an almost non-amyloid ascus (Fig. 5).

Aciculopsora cinerea Cáceres \& Lücking in Cáceres, Libri Botanici 22: 26. 2007.

(Fig. 2)

MycoBank MB 540283

Type: Brazil, Alagoas, Pilar, Reserva Particular do Patrimônio Natural (RPPN) Fazenda São Pedro (transect study), $9^{\circ} 37^{\prime} \mathrm{S}, 35^{\circ} 58^{\prime} \mathrm{W}, 50 \mathrm{~m}$ alt., Mata Atlântica (forest along main trail), 2001?, M. Cáceres A40-310 (B 600187496 - holotype!).

A detailed description is given by Cáceres (2007).

Habitat and distribution. The species is known from a single collection in the Atlantic Forest in Brazil (Alagoas State), where it was collected on bark in the forest along a main trail (Cáceres 2007).

Notes. The species differs from A. longispora and A. srilankensis mainly in forming smaller apothecia and shorter ascospores. As only a single specimen of this species is known, further specimens must be collected in order to circumscribe the full morphological variability of the species. Based on the single specimen's morphological characters (forming minute squamules on a black prothallus, dark lecideine apothecia), it very likely belongs in the genus Aciculopsora, but DNA sequences are needed to estimate the genetic distance to the other two Aciculopsora species and to exclude the possibility that it is merely a poorly developed specimen belonging to $A$. longispora or A. srilankensis.

Aciculopsora longispora (Swinscow \& Krog) Kistenich, Bendiksby \& Timdal, comb. nov.

(Fig. 3)

MycoBank MB 832301

Basionym: Phyllopsora longispora Swinscow \& Krog, Nord. J. Bot. 5: 493 (1985). Type: KENYA, Western Province, Kakamega District, Kakamega Forest, near Forest Station, $\sim 13 \mathrm{~km}$ ESE of Kakamega, $0^{\circ} 15^{\prime} \mathrm{N}, 34^{\circ} 52^{\prime} \mathrm{E}, \sim 1700 \mathrm{~m}$ alt., on trunk of a tree in dense rainforest, 20 Jan. 1970, R. Santesson 21698a (UPS L-055196 - holotype!).
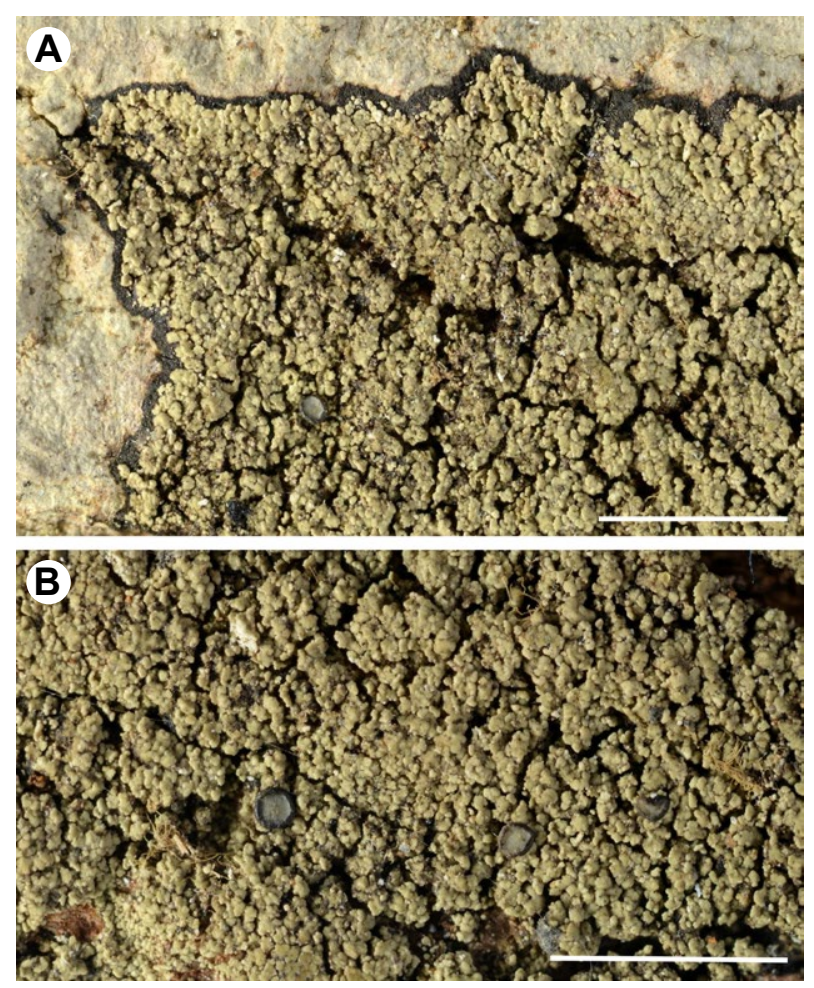

Figure 2. Habit of Aciculopsora cinerea (Cáceres A40-310, B). Photos E. Timdal. Scales: A-B $=2 \mathrm{~mm}$.

Aciculopsora salmonea Aptroot \& Trest in Aptroot et al., J. Hattori Bot. Lab. 100: 618 (2006). MycoBank: MB521261. Type: COSTA RICA, Prov. Guanacaste, Barra Honda National Park, $10^{\circ} 10^{\prime} \mathrm{N}, 85^{\circ} 21^{\prime} \mathrm{W}, 400-500 \mathrm{~m}$ alt., on tree bark of deciduous tree in dry semi-deciduous forest, 22 Mar. 2004, R. Lücking 17543 (CR - holotype, not seen; BR LICH-25048-22 - isotype!).

Detailed descriptions are given by Swinscow \& Krog (1985; as Phyllopsora longispora) and by Aptroot et al. (2006; as A. salmonea). In specimen \#1042 (Kenya) the ascospores are 30-44 $\times \sim 2-2.5 \mu \mathrm{m}(\mathrm{n}=20)$. In specimen \#7377 (Galapagos) the ascospores are $29-54 \times \sim 2-2.5 \mu \mathrm{m}(\mathrm{n}=20)$.

Habitat and distribution. The species is known from eight localities: two in Kenya (both in Kakamega National Park), two in Costa Rica (Barra Honda NP, Palo Verde NP), two in Ecuador (Galapagos NP, Yasuni NP) and two in Argentina (Uruguai Provincial Park, Cruce Caballero Provincial Park). All specimens were collected from tree trunks. The habitats ranged from dry semi-deciduous forest and abandoned farmland to Atlantic forest and dense rainforest.

Notes. Following the new combination, the species A. longispora is here shown to be present in both East Africa and the Neotropics. The species may be distinguished from the other two Aciculopsora species by forming bigger apothecia and slightly larger ascospores, as well as sometimes forming isidia. By adding six additional specimen collections to this species, we show that the presence of isidia is not a reliable diagnostic character for assigning a specimen to this species, since the specimens from Costa Rica are not isidiate, unlike the remaining specimens. Furthermore, the climatic range of the collected specimens from dry to wet tropical forest indicates strong ecological variability of moisture tolerance. 

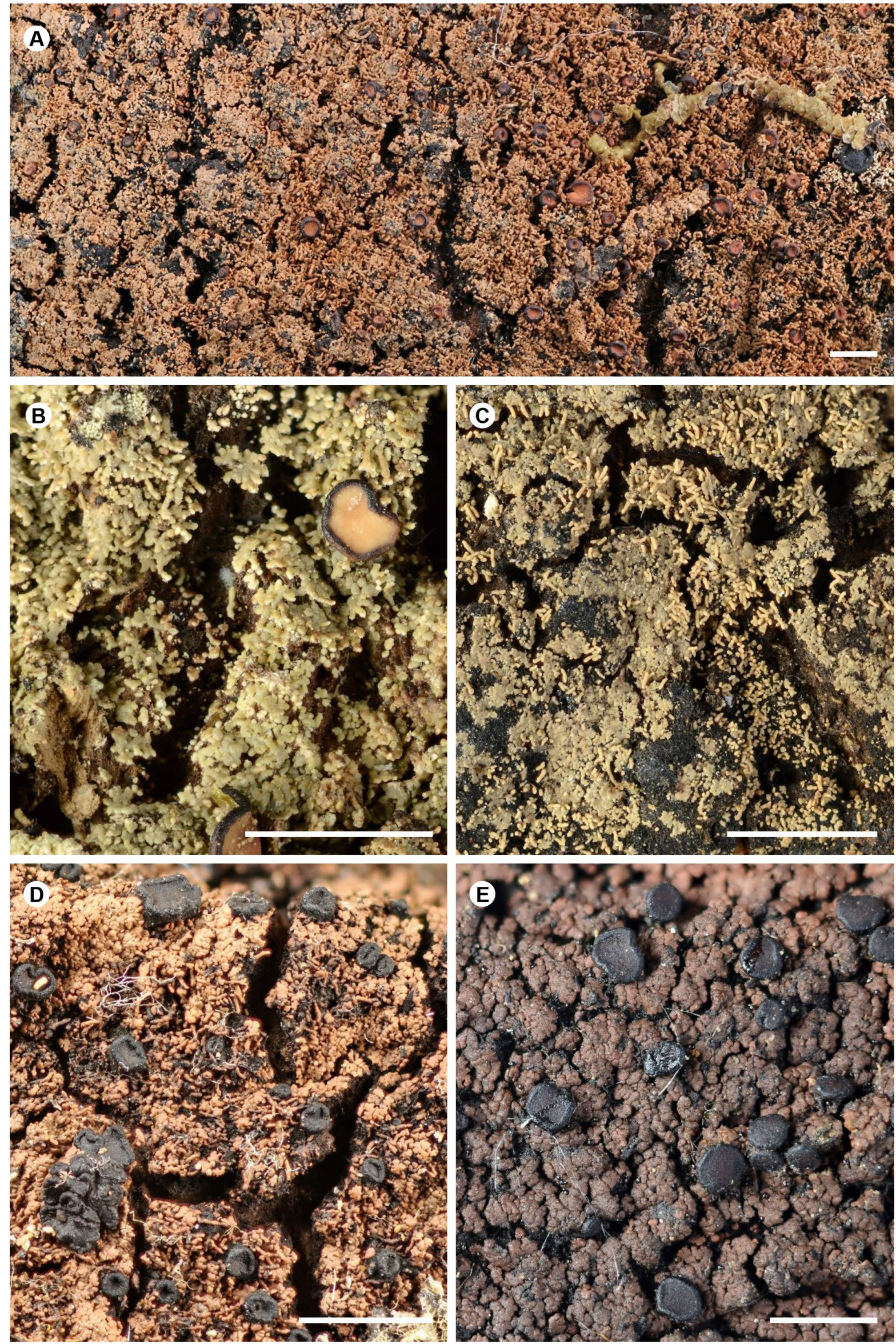

Figure 3. Habit of Aciculopsora longispora. A - holotype of Phyllopsora longispora (Santesson 21698a, UPS); B - new specimen from Kenya (Divakar, Lumbsch \& Mangold 19543O, herb. Pérez-Ortega); C - new specimen from Ecuador (Tihua, Macía, Palice, Romero \& Valencia 2833, herb. Z. Palice); D - new specimen from Galapagos (Bungartz 3699, CDS); E - isotype of Aciculopsora salmonea (Lücking 17543, BR). Photos E. Timdal. Scales: A-E $=2 \mathrm{~mm}$. 
Additional specimens examined. KENYA. Western Province, Kakamega National Park, southern part, near Nandamanyawa River, $0^{\circ} 24^{\prime} \mathrm{N}, 34^{\circ} 53^{\prime} \mathrm{E}, 1566 \mathrm{~m}$ alt., on tree trunk, 16 Jan. 2007, Divakar, Lumbsch \& Mangold 195430 (herb. Pérez-Ortega). ECUADOR. Galápagos, Santa Cruz, Isla Santa Cruz, abandoned farm along northern part of the loop road from Bellavista to Garrapatero, $0.68278^{\circ} \mathrm{S}, 90.30861^{\circ} \mathrm{W}, 255 \mathrm{~m}$ alt., humid zone, overgrown farm area with introduced trees including Cedrela odorata, Persea americana, Syzygium malaccense, Cestrum auriculatum and others, small open clearing in between, on bark, trunk of Pisonia floribunda ( $40 \mathrm{~cm}$ diam.), S-exposed, sunny, wind- and rain-exposed, 2006-02-19, F. Bungartz 3699 (CDS 27517); Prov. Napo, Yasuni National Park, Río Tiputini, rainforest near a community of Huoarani indians, not far from the local road ( $\mathrm{km} \mathrm{34}), 0^{\circ} 37^{\prime} \mathrm{S}, 76^{\circ} 28^{\prime} \mathrm{W}, \sim 300 \mathrm{~m}$ alt., on bark, 13-14 Aug. 1999, T. Ahue, M. Macía, Z. Palice, H. Romero \& R. Valencia 2833 (herb. Z. Palice). ARGENTINA. Misiones Province, General Manuel Belgrano Department, Parque Provincial Uruguai, $25.8579^{\circ} \mathrm{S}, 54.1680^{\circ} \mathrm{W}$, Alto Paraná Atlantic forest, epiphytic, 16 Apr 2019, A. Suija (TU-86951); San Pedro Department, Parque Provincial Cruce Caballero, $26.5204^{\circ} \mathrm{S}$, $53.9924^{\circ} \mathrm{W}$ ), forest with Araucaria angustifolia, epiphytic, 18 Apr 2019, A. Suija (TU-86950).

Aciculopsora srilankensis Kistenich, Bendiksby, Weerakoon \& Timdal, sp. nov.

(Fig. 4)

MycoBank MB 832302

Diagnosis: Differs from the other Aciculopsora species in forming soralia.

Type: Sri Lanka, North Western Province, Wilpattu National Park, $8^{\circ} 24.043^{\prime} \mathrm{N}, 7^{\circ} 58.656^{\prime} \mathrm{E}, 79 \mathrm{~m}$ alt., 1 Mar. 2017, G. Weerakoon WL060 (PDA - holotype!, BM - isotype!, O L-1315 - isotype!).

Thallus irregular, up to at least $3 \mathrm{~cm}$ diam., minutely squamiform; squamules adnate or partly ascending, up to $0.6 \mathrm{~mm}$ diam., \pm isodiametric to somewhat elongate, scattered when young, later contiguous or slightly imbricate, crenulate to incised, weakly convex, medium green, glabrous on upper side, glabrous or faintly pubescent along margin; soralia patchily developed, originating from the margin of the squamules, later \pm coalescing, pale green, farinose; soredia simple, 20-40 $\mu \mathrm{m}$ diam.; isidia absent; upper cortex 10-20 $\mu \mathrm{m}$ thick, paraplectenchymateous, composed of thin-walled hyphae with rounded lumina, not containing crystals; algal layer $50-70 \mu \mathrm{m}$; algal cells up to $12 \mu \mathrm{m}$ diam.; medulla not containing crystals; prothallus well developed, dark reddish brown. Apothecia up to $1 \mathrm{~mm}$ diam., rounded when young, later often somewhat irregular, simple or sometimes conglomerate, plane to moderately convex, pale to medium brown, sometimes patchily dark brown, with an indistinct, concolorous to darker, glabrous margin; excipulum pale brown to colourless, composed of radiating, conglutinated, rather thick-walled hyphae with broadly ellipsoid to shortly cylindrical lumina; hypothecium colourless; epithecium colourless; no crystals in apothecia; ascus narrowly clavate, with a well-developed, faintly amyloid tholus containing a conical, somewhat deeper amyloid structure; ascospores acicular, straight or slightly curved, rarely spirally arranged in ascus, simple or with a few scattered septa, $24-41 \times \sim 2-2.5 \mu \mathrm{m}(\mathrm{n}=20)$. Conidiomata not seen. Chemistry. No lichen substances (by TLC).
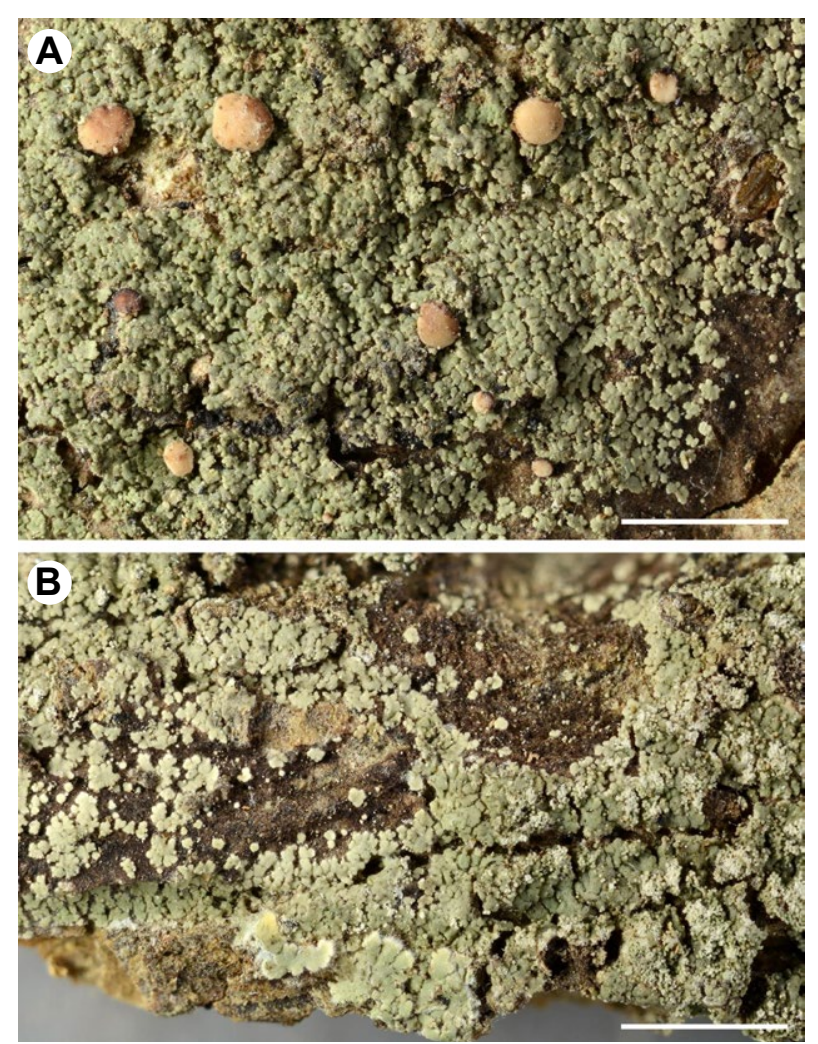

Figure 4. Habit of Aciculopsora srilankensis described here as new. A - holotype (Weerakoon WL060, PDA); B - additional specimen with soredia (Weerakoon WL15/2, PDA). Photos E. Timdal. Scales: $\mathrm{A}-\mathrm{B}=2 \mathrm{~mm}$.

Habitat and distribution. The species is known only from the type locality in Wilpattu National Park in Sri Lanka, where it grows on ebony (Diospyros ebenum) in low scrub monsoon forest with tall emergents, such as palu (Manilkara hexandra), satin (Chloroxylon swietenia), milla (Vitex altissima) and weera (Drypetes sepiaria).

Notes. The species differs from the other Aciculopsora species in being sorediate. It may be confused mainly with 'Phyllopsora' sorediata, described from Thailand (Aptroot et al. 2007), which Kistenich et al. (2018) recovered in clade ' $\mathrm{C}$ ' of the Ramalinaceae (within the genus Bacidia). That species differs in containing lichen substances (atranorin, divaricatic acid and zeorin in the holotype) and in having an entirely pale brown apothecial margin. 'Phyllopsora' soralifera, described from Peru (Timdal 2008), is also morphologically similar, but differs in forming more capitate, not coalescing soralia, having persistently pale brown apothecia, and in lacking a prothallus. It was sequenced by Kistenich et al. (2019a) and excluded from Phyllopsora but was left with no generic placement. Phyllopsora catervisorediata, a morphologically similar species described from the Indian Himalayas (Mishra et al. 2011), has not been examined by us due to a lack of response from LWG to our repeated loan requests, but apparently it differs in containing crystals in the medulla, showing atranorin by TLC, and in having an indistinct prothallus; apothecia are unknown.

Additional specimen examined. SRI LANKA, same locality and date as for holotype, G. Weerakoon WL17/2 (PDA). 

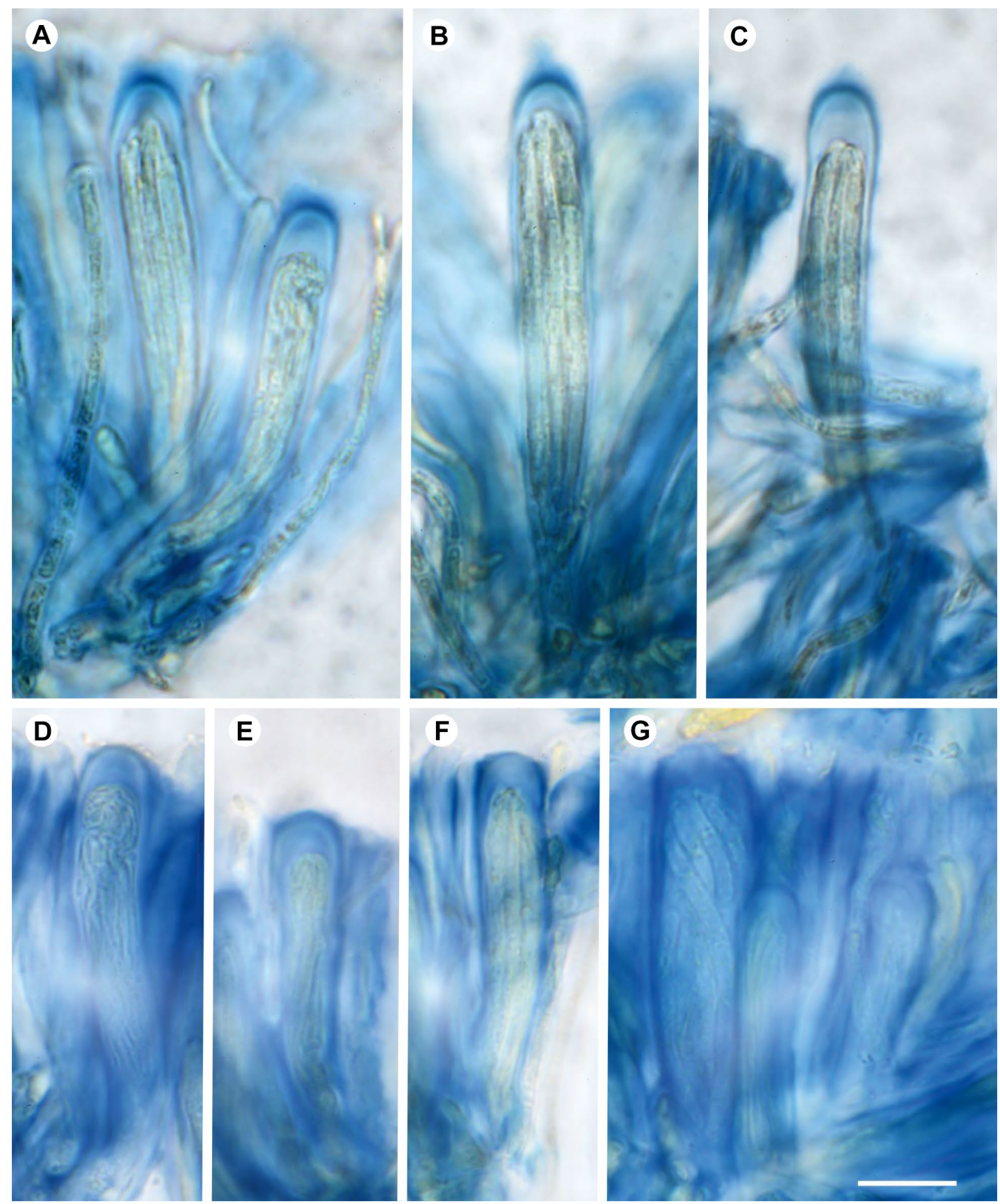

Figure 5. Asci with ascospores and paraphyses in modified Lugol's solution (water replaced by $50 \%$ lactic acid) after pretreatment in $10 \% \mathrm{KOH}$. A-C - asci in Aciculopsora longispora (Divakar, Lumbsch \& Mangold 19543O, herb. Pérez-Ortega); D-G - asci in A. srilankensis (Weerakoon WL060, PDA). Photos E. Timdal. Scale $=10 \mu \mathrm{m}$ for all photos.

\section{Key to the species of Aciculopsora}

1 Thallus sorediate, not isidiate ...... A. srilankensis Thallus not sorediate, isidiate or not .........

2(1) Apothecia up to $0.5 \mathrm{~mm}$ diam., with grey disc; ascospores $18-25 \mu \mathrm{m}$ long .................... cinerea

Apothecia up to $1.5(-1.8) \mathrm{mm}$ diam., with pale brown to dark brown disc; ascospores $30-55 \mu \mathrm{m}$ long ...... $\ldots \ldots \ldots \ldots \ldots \ldots \ldots \ldots$ A. longispora

\section{Acknowledgements}

We are grateful to the following herbaria for providing loans of material for our study: B, BR, CDS, PDA, UPS, and the private herbaria of Z. Palice and S. Pérez-Ortega. We thank A. Suija for providing us with the ITS sequences of the two specimens from Argentina, and F. Bungartz for the specimen of A. longispora from Galapagos. This specimen was studied as part of the Galapagos Lichen Inventory in collaboration with Ecuador's national biodiversity assessment 'Biodiversidad Genética del Ecuador' by the Instituto Nacional de Biodiversidad del Ecuador (INABIO). For research and specimen permits we are particularly indebted to D. Rueda, D. L. Solís, G. Quedaza and V. Carrión from the Dirección del Parque Nacional Galápagos (DPNG), and D. Inclán, F. Prieto and R. Batallas (INABIO). This is contribution no. 2304 of the Charles Darwin Foundation for the Galapagos Islands. GW is grateful for research funding received from the National Geographic Society (USA) and Dilmah Conservation (Sri Lanka) to conduct fieldwork in Sri Lanka in 2017. GW thanks the Forest and Wildlife departments of Sri Lanka for collecting and export permits, and 
wishes to extend her gratitude to P. Wolseley, A. Aptroot, Prof. S. Wijesundara and the research team. ET, MB and SK thank S. Rui for curatorial assistance.

\section{References}

Altekar, G., Dwarkadas, S., Huelsenbeck, J. P. \& Ronquist, F. 2004. Parallel metropolis coupled Markov chain Monte Carlo for Bayesian phylogenetic inference. Bioinformatics 20: 407-415.

Aptroot, A., Saipunkaew, W., Sipman, H., Sparrius, L. \& Wolseley, P. 2007. New lichens from Thailand, mainly microlichens from Chiang Mai. Fungal Diversity 24: 75-134.

Aptroot, A., Umaña, L., Chaves, J. L. \& Trest, M. T. 2006. A first assessment of the Ticolichen Biodiversity inventory in Costa Rica: three new squamulose genera (Lecanorales: Ramalinaceae and Pilocarpaceae). The Journal of the Hattori Botanical Laboratory 100: 617-623.

Cáceres, M. E. S. 2007. The corticolous crustose and microfoliose Lichens of Northeastern Brazil-diversity, ecology, and conservation. PhD-thesis. University of Bayreuth, Germany.

Chernomor, O., von Haeseler, A. \& Minh, B. Q. 2016. Terrace aware data structure for phylogenomic inference from supermatrices. Systematic Biology 65: 997-1008.

Kalyaanamoorthy, S., Minh, B. Q., Wong, T. K. F., von Haeseler, A. \& Jermiin, L. S. 2017. ModelFinder: fast model selection for accurate phylogenetic estimates. Nature Methods 14: 587.

Kauff, F. \& Lutzoni, F. 2002. Phylogeny of the Gyalectales and Ostropales (Ascomycota, Fungi): among and within order relationships based on nuclear ribosomal RNA small and large subunits. Molecular Phylogenetetics and Evolution 25: 138-156.

Kearse, M., Moir, R., Wilson, A., Stones-Havas, S., Cheung, M., Sturrock, S., Buxton, S., Cooper, A., Markowitz, S. \& Duran, C. 2012. Geneious Basic: an integrated and extendable desktop software platform for the organization and analysis of sequence data. Bioinformics 28: 1647-1649.

Kistenich, S., Timdal, E., Bendiksby, M. \& Ekman, S. 2018a. Molecular systematics and character evolution in the lichen family Ramalinaceae (Ascomycota: Lecanorales). Taxon 67: 871-904.

Kistenich, S., Rikkinen, J., Thüs, H., Vairappan, C., Wolseley, P. A. \& Timdal, E. 2018b. Three new species of Krogia (Ramalinaceae, lichenized Ascomycota) from the Paleotropics. MycoKeys 40: 69-88.

Kistenich, S., Bendiksby, M., Ekman, S., Cáceres, M. E. S., Hernández, J. E. \& Timdal, E. 2019a. Towards an integrative taxonomy of Phyllopsora (Ramalinaceae). The Lichenologist 51: 323-392.

Kistenich, S., Bendiksby, M., Vairappan, C. S., Weerakoon, G., Wijesundara, S., Wolseley, P. A. \& Timdal, E. 2019b. A regional study of the genus Phyllopsora (Ramalinaceae) in Asia and Melanesia. MycoKeys 53: 23-72.

Marchese, C. 2015. Biodiversity hotspots: A shortcut for a more complicated concept. Global Ecology and Conservation 3: 297-309.

Mishra, G. K., Upreti, D. K., Nayaka, S. \& Haridas, B. 2011. New taxa and new reports of Phyllopsora (lichenized Ascomycotina) from India. Mycotaxon 115: 29-44.

Nguyen, L.-T., Schmidt, H. A., von Haeseler, A. \& Minh, B. Q. 2015. IQ-TREE: A fast and effective stochastic algorithm for estimating maximum-likelihood phylogenies. Molecular Biology and Evolution 32: $268-274$.

Ronquist, F. \& Huelsenbeck, J. P. 2003. MrBayes 3: Bayesian phylogenetic inference under mixed models. Bioinformatics 19: 1572-1574.

Stöver, B. C. \& Müller, K. F. 2010. TreeGraph 2: Combining and visualizing evidence from different phylogenetic analyses. $B M C$ Bioinformatics 11: 7.

Swinscow, T. D. V. \& Krog, H. 1985. Phyllopsora longispora sp. nov. Nordic Journal of Botany 5: 493-495.

Timdal, E. 2008. Studies on Phyllopsora (Ramalinaceae) in Peru. The Lichenologist 40: 337-362. 